\title{
Remediation and development of a former rubber products manufacturing facility in Colorado, USA
}

\author{
J. V. Accashian ${ }^{1}$, R. L. Olsen ${ }^{1}$ \& D. C. Mosteller ${ }^{2}$ \\ ${ }^{1}$ CDM, Denver, Colorado, USA \\ ${ }^{2}$ Mosteller Consulting, LLC, USA
}

\begin{abstract}
A former rubber manufacturing site occupies 80 acres approximately $5 \mathrm{~km}$ south of the Denver, Colorado, USA downtown business area. The facility manufactured tires, belts, and hoses for automotive and industrial businesses and ceased operations in 1995. Despite abandoned buildings and contaminated soil and groundwater, the site was an attractive location for redevelopment because of its proximity to major transportation thoroughfares (including highways and light rail) and to downtown Denver (major entertainment facilities and workplaces). After manufacturing operations ceased, several developers specializing in brownfield properties expressed interest in transforming the site into a major transit-oriented development (TOD) with residential units, office space, and retail facilities and subsequently purchased portions of the site. A 5acre part of the site was the first area to be remediated and redeveloped. The main areas of the 5-acre property requiring remediation had soil contaminated with petroleum hydrocarbons (TPH) and groundwater contaminated with trichloroethene (TCE) and 1,1-dichloroethene (1,1-DCE). The contaminated soils were excavated and properly disposed off site. The contaminated groundwater was remediated using in situ chemical oxidation techniques by injecting a solution of potassium permanganate into the soils and groundwater. The remediation activities were performed under the provisions of the Colorado Department of Public Health and Environment's Voluntary Cleanup Program (VCUP). The remediation approach and VCUP resulted in rapidly achieving a regulatory no further action determination. The 5-acre property was sold to a commercial developer which has developed a residential and commercial complex consisting of apartments and retail space. Other parts of the site have also been redeveloped or are undergoing remedial activities.
\end{abstract}


Keywords: contaminated sites, cleanup, remediation, redevelopment, brownfield, TOD.

\section{Introduction}

The investigation, remediation, and development of contaminated sites in the United States occurs in many different ways using various approaches depending upon the type/extent of contamination, the environmental and human health risk, the regulatory authorities, the remediation cost, the site owners/developers, and the property value and demand [1-4]. The former 80 -acre rubber manufacturing site is a potential commercial and residential development located in Denver, Colorado, USA, approximately $5 \mathrm{~km}$ south of the downtown area of Denver (see Figure 1). The site is attractive for development because of its proximity to major transportation thoroughfares (Interstate Highway 25, light rail) and downtown Denver (major sports arenas, amusement park, museums, financial business centers, and workplaces).

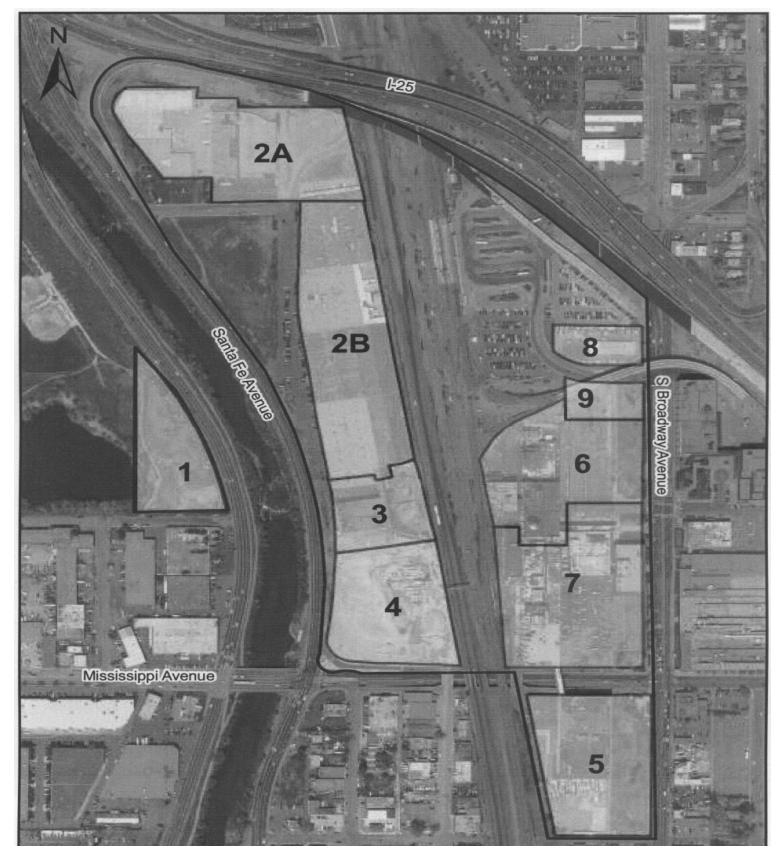

Figure 1: $\quad$ Site location.

The focus of this paper is the remediation and development of a 5-acre parcel of the former rubber manufacturing site (area 5 in Figure 1). Remedial investigations, planning, and actions were directed by CDM with support of various subcontractors including excavation and chemical injection specialists.

This paper discusses the following items: 
- Site background, including types and sources of contamination

- Remediation activities

- Development activities

- Conclusions

\section{Description of the 5-acre project parcel}

\subsection{Site background}

Based on a review of aerial photographs and Sanborn Maps from the mid- to late- 1920s, the land encompassing the 5-acre project area was originally occupied by a creamery located along the east side of the parcel and fronting $\mathrm{S}$. Broadway. Historically, there were several other businesses located along the eastern side of the parcel. These businesses included a roofing company, a used car dealership, and a service station last operated by Chevron. Address records for the area indicate an auto service or service station first existed in the late 1940s. By 1961, the address records list the service station as the Chevron Broadway gas station and remained listed as such through at least 1976. A 1977 aerial photograph for the area indicates the service station no longer exists.

At the start of remediation, two buildings existed on the project parcel: Units 20 and 21, which were constructed in 1950 and 1945, respectively. Unit 20 was a four-story building of concrete construction with a full basement structure. Unit 20 was used for industrial belt manufacturing, tire finishing, urethane production, and tire testing. A print shop and darkroom was located in the basement of Unit 20 until operations ceased in December 2002.

Unit 21 was a single-story building of brick and concrete construction with a full basement. The building was used for industrial belt manufacturing, later housed a carpentry shop, and a print screening shop. The portions of the former Unit 21 shop used for screen preparations were located in the west and northwest areas of the Unit 21 basement. Print shop operations ceased in December 2002 when the rubber manufacturer vacated the building.

A third building that previously existed on the project parcel, former Unit 22, was located at the south end of the property. Built in 1945, Unit 22 was a singlestory brick building constructed on a concrete slab. According to discussions with former employees, Unit 22 was variously used as an automotive maintenance garage, a storage area, and a steam cleaning area until it was demolished in the mid-1970s. An under floor drain system for the building was connected to a sump located in the north end of the building. A steam cleaning wash rack was located in the north end of Unit 22 where a drain pan in the concrete floor directed flow to a grease trap and the sump. The sump apparently was connected to a sanitary sewer outlet. Oily, dirty, rubber-caked equipment was soaked in caustic solution baths and then steam cleaned on the racks in this portion of the building.

A 10,000-gallon underground storage tank (UST) was located immediately to the west of Unit 22. Historical drawings indicate the UST was originally intended for gasoline storage, but anecdotal evidence indicates the primary use was for diesel fuel storage. The UST was removed in the mid-1970s at the same 
time Unit 22 was demolished. There are no public records available documenting the removal of the UST. An excavation at the site in 1995 verified that there were no USTs remaining in place.

\subsection{Project parcel physical setting}

The project parcel is bounded on the east and south by commercial/residential property, on the north by industrial property (including major portions of the former rubber manufacturing site), and on the west by the Denver and Rio Grande Western Railroad right-of-way (ROW). The project parcel covers approximately 5 acres and lies at an elevation of approximately 5,270 feet above mean sea level (ft. AMSL). The project parcel's surface topography slopes at approximately 0.7 to 1.5 percent towards the west-northwest.

The site is located on alluvial terrace deposits in the South Platte valley within the Denver Basin. The water-bearing terrace deposits include the Piney Creek and Post-Piney Creek Alluvium consisting of slit and sand with gravelly soil, which varies in thickness from a few feet to approximately 50-ft. thick. Depth to groundwater beneath the site varies from approximately 4 to $20 \mathrm{ft}$. below ground surface (bgs) in the west and central portion of the site to approximately 14 to $23 \mathrm{ft}$. bgs in the central southeast portion. The bedrock immediately beneath consists of weathered claystones, sandstones, and siltstones of the Denver formation. The weathered bedrock surface forms an erosional terrace that breaks in slope toward the South Platte River under the Santa Fe and Burlington Northern railroad lines. Regional water supply aquifers exist within the Arapahoe, Laramie, and Fox Hills formations, which are stratigraphically several hundred feet below the Denver formation. There are occasional waterbearing intervals in the Denver Formation that are reportedly used for water supply in the Denver Basin.

\section{Project parcel remediation}

\subsection{Nature and extent of contamination}

Impacts to soil and groundwater have been identified on the project parcel in two areas: former Unit 22 and former Chevron gas station (Figures 2 and 3).

\subsubsection{Former unit 22}

The former Unit 22 area is characterized by two distinct areas of contamination;

- Total petroleum hydrocarbon (TPH)-containing soil associated with the former Unit 22 diesel fuel UST.

- Trichloroethene (TCE)-containing groundwater associated with the former Unit 22 wash rack and sump area.

The TPH-containing soil was associated with a former diesel fuel UST that was removed in the mid-1970s. A portion of the soil affected by the former UST was excavated in 1995; however, low-level residual TPH-containing soil contamination greater than 500 milligrams per kilogram $(\mathrm{mg} / \mathrm{kg})$ remained in an area north and west of the 1995 excavation limits. Although the Colorado Department of Public Health and Environment (CDPHE) did not require further 


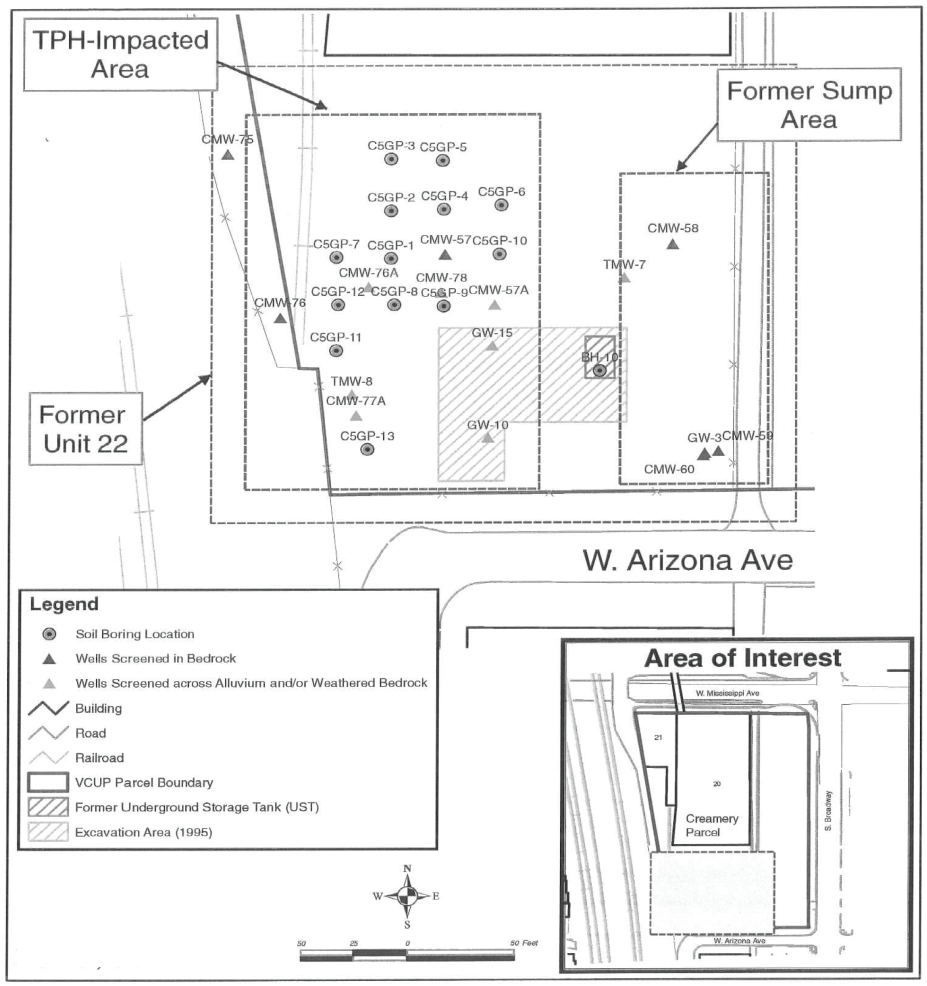

Figure 2: $\quad$ Former unit 22.

removal of this residual TPH-containing soil, the city and county of Denver (CCD) did require removal of TPH-containing soil where concentrations are greater than the $500 \mathrm{mg} / \mathrm{kg}$ threshold within existing or future CCD right-of-way (ROW).

The source of the TCE contamination was identified as the grease trap and drainage pit sumps associated with the former Unit 22 wash rack area. In 2004, the two sumps were removed along with approximately 3 cubic yards of soil. The former grease trap sump, a concrete structure, had dimensions of approximately $5 \mathrm{ft}$. by $5 \mathrm{ft}$. by $8 \mathrm{ft}$. in depth. The former drainage pit sump, approximately $5 \mathrm{ft}$. in diameter and $10 \mathrm{ft}$. in depth, was constructed of brick, mortar, and concrete.

TCE was the only contaminant in groundwater associated with the former sumps that exceeded CDPHE cleanup goals and standards. Concentrations of up to $130 \mu \mathrm{g} / \mathrm{L}$ have been measured. Groundwater is approximately $14 \mathrm{ft}$. bgs in this area. Based on groundwater data, groundwater flow direction is generally to the west/southwest in the former Unit 22 area. The subsurface in this area is characterized by alluvium consisting of silts and clays overlying sand and gravelly sand to approximately $14 \mathrm{ft}$. bgs. The alluvium is underlain by the Denver Formation. 


\subsubsection{Former Chevron gas station}

Groundwater associated with the former Chevron gas station portion of the project parcel is affected primarily with low concentrations of 1,1-dichloroethene (1,1-DCE) from an unknown source. 1,1-DCE is the only contaminant in this area that exceeds CDPHE cleanup goals and standards.

Depth to groundwater is approximately $20 \mathrm{ft}$. bgs in the area of the former Chevron station. Based on groundwater data, groundwater flow direction is generally to north/northeast in the former Chevron gas station area. Alluvium consisting of silts and clays overlying sand and gravelly sand is present to approximately $18 \mathrm{ft}$. in the area of the former Chevron station.

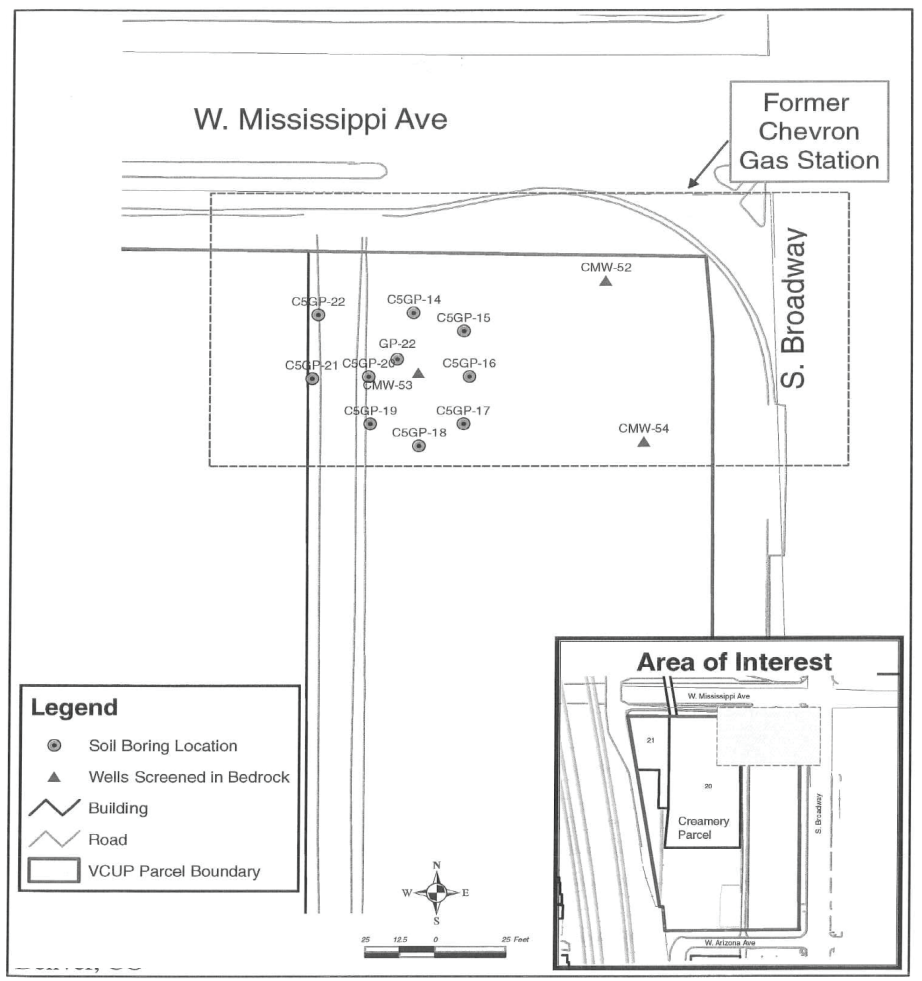

Figure 3: Former Chevron gas station.

\subsection{Regulations and remediation objectives}

The remediation activities were performed under provisions of the CDPHE's Voluntary Cleanup Program (VCUP). The objective of VCUP is to facilitate the redevelopment and transfer of contaminated properties. The program provides timely (45 days) review of cleanup plans submitted by property owners. Cleanup decisions are based on existing standards and the proposed use of the property. The actual cleanup and verification is the owner's responsibility. The program 
provides public and private property owners with the resources to facilitate cleanups as well as assurances against regulatory enforcement. VCUP is a way to get both federal and state remedial plans approved in a one-stop shop.

The overall goal of the remediation was to achieve regulatory closure by obtaining a no action determination (NAD) status from the CDPHE. The remediation strategy was designed to meet the objectives outlined in Table 1 and was carried out in two phases. Phase 1 of the proposed strategy included: (1) aggressive remediation of the most heavily contaminated areas through removal of existing source area structures and adjacent soils, followed by backfilling with clean materials; and (2) installation of a piping network to deliver amendments to the subsurface during Phase 2 in situ remediation activities. Phase 2 of the proposed strategy included: (1) a series of subsurface chemical oxidant injections to reduce residual contaminant concentrations and (2) subsequent monitoring of the soil and groundwater to document the performance of the completed remediation activities.

Table 1: $\quad$ Remedial action objectives.

\begin{tabular}{|c|c|}
\hline $\begin{array}{l}\text { Monitoring } \\
\text { Locations }\end{array}$ & Qualitative Remedial Action Objectives \\
\hline \multirow{3}{*}{$\begin{array}{l}\text { Source Area } \\
\text { Performance } \\
\text { Monitoring } \\
\text { Locations }\end{array}$} & $\begin{array}{l}\text { 1. Significantly reduce the contaminant mass in soil and groundwater } \\
\text { within each of the former source areas. }\end{array}$ \\
\hline & $\begin{array}{l}\text { 2. Demonstrate through ongoing monitoring that there are no } \\
\text { significant increases in groundwater contaminant concentrations at } \\
\text { any onsite monitoring wells. }\end{array}$ \\
\hline & $\begin{array}{l}\text { 3. Demonstrate that residual soil and groundwater concentrations are } \\
\text { protective of human health for the proposed land uses. }\end{array}$ \\
\hline $\begin{array}{l}\text { Compliance Wells } \\
\text { (at or near the } \\
\text { property } \\
\text { boundary) }\end{array}$ & $\begin{array}{l}\text { 4. Demonstrate attainment of MCLs in groundwater within a } \\
\text { reasonable timeframe when compared with alternative remediation } \\
\text { approaches and/or declining contaminant concentrations which } \\
\text { indicate that attainment of MCLs is imminent. }\end{array}$ \\
\hline
\end{tabular}

Note: MCLs = maximum contaminant levels intended for a drinking water use; $\mathrm{TCE}=5 \mu \mathrm{g} / \mathrm{L} ; 1,1$-DCE $=7 \mu \mathrm{g} / \mathrm{L}$

\subsection{Remediation activities}

\subsubsection{TPH-impacted areas}

The TPH-containing soil was associated with a former diesel fuel UST that was removed in the mid-1970s. A portion of the soil affected by the former UST was excavated in 1995; however, low-level residual TPH-containing remained in an area north and west of the 1995 excavation limits. As noted above, portions of the TPH-containing area had residual soil contamination greater than $500 \mathrm{mg} / \mathrm{kg}$ and were within areas that were to be dedicated to the CCD for future use as roads, ROW, parks, or other land uses. Based on the intended future use of this area, CCD required removal of TPH-containing soil where concentrations are greater than $500 \mathrm{mg} / \mathrm{kg}$ within an existing or future CCD ROW. Although the contaminated soils within the TPH area have not adversely affected groundwater above CDPHE cleanup goals and standards, this area showed evidence of residual chlorinated volatile organic compounds (VOCs) in groundwater that originated from the upgradient former Unit 22 wash rack and sump areas. 
The remediation program for the TPH-containing area included the implementation of the following activities:

- Excavation of TPH-containing soil beyond the 1995 UST soil excavation limits to a depth of approximately 1 to $2 \mathrm{ft}$. into the weathered bedrock, or refusal, whichever came first.

- Backfilling of the TPH-containing soil excavation area with excavated soils that were confirmed to contain less than $500 \mathrm{mg} / \mathrm{kg}$ of TPH (based on offsite laboratory analyses) and with certified clean imported soil. During backfilling, three separate celled units of similar size were created. Each cell was separated by the compaction of native lowpermeability soils. Three injection headers and corresponding perforated lateral pipe were installed within each of the three celled areas.

TPH-containing soil associated with the former diesel UST at Unit 22 was excavated in March 2005. Excavation was completed vertically along West Arizona Avenue to the south of the site, and for approximately $40 \mathrm{ft}$. along the western side of the site. Vertical excavation was facilitated by shoring to protect an active water main and other major utilities located in West Arizona Avenue. The other areas on the northwest, north, and east sides of the site were excavated with a 1.5:1 side slope. Figure 4 shows the approximate extent of the excavation in the TPH-containing area.

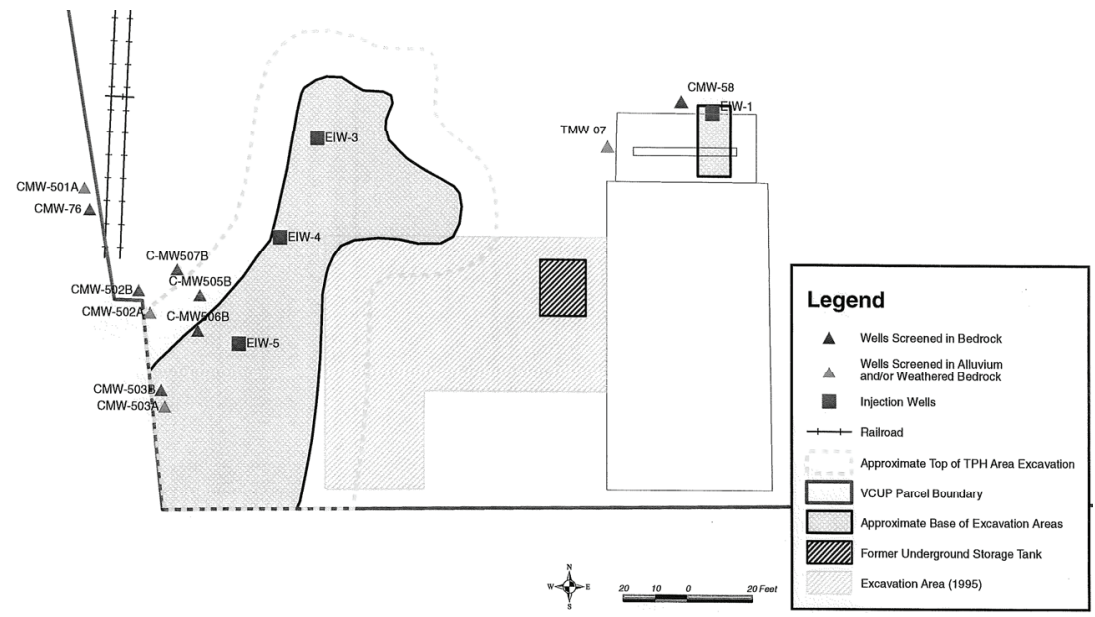

Figure 4: TPH-impacted excavation area and injection/monitoring wells.

The excavator removed material 1 to $2 \mathrm{ft}$. into the weathered bedrock interface or until refusal was reached throughout the base of the TPH-containing area. The maximum depth of excavation was approximately $18 \mathrm{ft}$. Consistent with the estimate of total in-place volume of clean soil to be excavated, approximately 7,000 cubic yards of soil were excavated from the TPH and former sump areas. These soils were screened for potential contamination, placed 
outside the excavation limits, and reinstalled upon completion of the soil removal activities.

Post-excavation documentation soil samples were collected from the sidewalls and base of the TPH-containing soil excavation. Potholes were advanced for sampling at a spacing of every 100 linear $\mathrm{ft}$. around the edge of the area. Samples were collected from these holes from both the capillary fringe and saturated zone. Additionally, potholes were created at the base of the excavation. All samples were analyzed for TPH (DRO/GRO) using USEPA Method 8015B. One sample contained contamination greater than $500 \mathrm{mg} / \mathrm{kg}$ DRO requiring additional excavation (1,480 cubic yards). Subsequent sampling verifies that the remediation goal of the TPH less than $500 \mathrm{mg} / \mathrm{kg}$ had been achieved.

Certified clean backfill was brought onto the site for use as backfill material. Approximately 1,660 cubic yards of material was imported for both the TPHcontaining area and former sump areas. The clean fill was placed in the TPHcontaining area after the native soil suitable for replacement was returned to the excavation area.

The infiltration gallery in the TPH-containing area, which consisted of three separate celled units, was constructed after excavation. Wells EIW-3, EIW-4, and EIW-5 were installed, with EIW-3 being the northernmost and EIW-5 being the southernmost well, as presented in Figure 4. Steps in constructing the infiltration gallery include the following:

- One foot of permeable backfill material was added to the base of the excavation.

- Placement of 4-inch corrugated high-density polyethylene (HDPE) drain pipe with 2.3 square inches/feet open area overlain by filter fabric in base of the excavation on top of the $1 \mathrm{ft}$. of fill material. The drain line was constructed below the bedrock elevation. HDPE pipe was connected to a 4 -inch vertical schedule 40 polyvinyl chloride (PVC) header pipe.

- Permeable backfill material was brought to within 8 to $10 \mathrm{ft}$. of the surface, installing a layer over the pipe using minimal drop height to protect the pipe from impact damage.

- Geotextile was placed at the top of the permeable backfill to prevent infiltration of fine grained material into the gravel. Filling and compaction was completed using acceptable native soils as needed.

Approximately 370 linear ft. of horizontal header piping was installed, in addition to approximately 65 linear $\mathrm{ft}$. of vertical header piping, which was used for chemical injection at the TPH-area infiltration galleries.

\subsubsection{Former wash rack and sump area}

The likely source of TCE contamination was the operation of a steam cleaning wash rack area and associated sumps in former Unit 22. A waste characterization sample collected from inside one sump indicated the presence of high concentrations of chlorinated solvents and associated breakdown products. TCE was the only contaminant identified in the sumps that was also detected in groundwater at concentrations that exceeded the CDPHE cleanup goals. 
Following the initial removal of the sumps, further remediation took place beginning in March 2005 and included expansion of the excavation area (180 cubic yards) and installation of one injection header (EIW-1).

\subsubsection{Groundwater remediation}

In situ chemical oxidation (ISCO) treatment was believed to offer the greatest potential to achieve a rapid reduction of the groundwater contaminant concentration ranges for TCE. ISCO involves the introduction of chemical oxidants, in this case potassium permanganate $\left(\mathrm{KMnO}_{4}\right)$, into the subsurface to remediate organic contaminants in soil and groundwater. Although $\mathrm{KMnO}_{4}$ does not effectively treat TPH contamination, injection of $\mathrm{KMnO}_{4}$ was performed in the TPH-containing area to address residual chlorinated VOCs in groundwater associated with the upgradient former Unit 22 wash rack and sump areas.

The subsurface ISCO injections were performed in accordance with the current EPA Underground Injection Control Program (UIC) Rule Authorization for the site that permits the subsurface injection of $\mathrm{KMnO}_{4}$ solutions. Injection activities consisted of multiple injection events of a $\mathrm{KMnO}_{4}$ solution to reduce residual TCE concentrations in groundwater and soil following excavation activities. These injection activities occurred at the three injection header pipes installed in the TPH-containing area and the single injection header pipe at the former sump area in April and May 2005. Additional injections also occurred at various wells throughout the site in May and November 2005.

The soil oxidant consumption for the TPH-containing and former sump areas at high dose for 48 hours ranged from 5.5 to $8.4 \mathrm{~g} / \mathrm{kg}$ and 5.7 to $9.4 \mathrm{~g} / \mathrm{kg}$, respectively (overall mean $=7.3 \mathrm{~g} / \mathrm{kg}$ ). For design purposes, the oxidant consumption was assumed to increase for long-term contact to $15 \mathrm{~g} / \mathrm{kg}$ of soil. The oxidant demand from the dissolved and sorbed contaminant is negligible compared to the soil oxidant demand. A 2-percent maximum concentration of $\mathrm{KMnO}_{4}$ solution was targeted for the injections at these areas to minimize any precipitation of permanganate solids in the injection solution and the delivery piping.

The desired concentration of $\mathrm{KMnO}_{4}$ was prepared in a mixing tank fed by a calibrated continuous dry feed system supplied with potable water obtained from a local hydrant. The $\mathrm{KMnO}_{4}$ was delivered to the subsurface using a selfcontained injection unit capable of regulating pressure, flow rate, and volume.

Table 2 summarizes the $\mathrm{KMnO}_{4}$ injection volumes and concentrations used during the injection events.

Additional small amounts of $\mathrm{KMnO}_{4}$ were injected into selected monitoring wells in May and November 2005.

Baseline groundwater monitoring, performance monitoring 30 days after each injection, and quarterly monitoring were performed. Sample results indicated attainment of MCLs in all but one monitoring well $(13 \mu \mathrm{g} / \mathrm{L}$ TCE at CMW502A). Additional injection/monitoring wells were installed north, south, and east of CMW-502A. Sampling results showed no additional VOCs (TCE) in the area. Therefore, no further action was necessary. 
Table 2: $\quad$ Summary of groundwater injection activities.

\begin{tabular}{|c|c|c|c|}
\hline & Date & $\begin{array}{c}\text { Volume of 2\% KMnO } \\
\text { injected (gal) }\end{array}$ & $\begin{array}{c}\text { Total Mass } \\
\text { KMnO }_{\mathbf{4}} \text { (lbs) }\end{array}$ \\
\hline \multirow{2}{*}{ Former Sump Area } & \multicolumn{3}{|c|}{} \\
\hline \multirow{2}{*}{ EIW-1 } & $4 / 19 / 2005$ & 31,000 & 5,167 \\
\cline { 2 - 4 } & $5 / 18 / 2005$ & 5,000 & 833 \\
\hline \multirow{2}{*}{ TPH-Containing Area } & \multicolumn{3}{|c|}{} \\
\hline \multirow{2}{*}{ EIW-3 } & $4 / 18 / 2005$ & 7,200 & 1,200 \\
\cline { 2 - 4 } & $5 / 18-5 / 20 / 2005$ & 15,132 & 2,522 \\
\hline \multirow{2}{*}{ EIW-4 } & $4 / 18 / 2005$ & 3,600 & 600 \\
\cline { 2 - 4 } & $5 / 18-5 / 20 / 2005$ & 5,600 & 933 \\
\hline \multirow{2}{*}{ EIW-5 } & $4 / 18 / 2005$ & 3,600 & 600 \\
\cline { 2 - 4 } & $5 / 18-5 / 20 / 2005$ & 18,732 & 3,122 \\
\hline
\end{tabular}

\subsubsection{Former Chevron gas station}

The only contaminant of concern detected in groundwater at the former Chevron gas station was 1,1-DCE. Extensive investigation on the site was unable to definitively locate the source of the 1,1-DCE contamination. Three separate investigations (i.e., resistivity survey, soil gas survey, and hydraulic connectivity testing) were performed in an effort to identify a source of 1,1-DCE contamination on the site. The resistivity survey concluded that (1) no subsurface tanks, sump structures, or other likely source features were evident; and (2) further subsurface investigations were not warranted. The soil gas survey indicated that 1,1-DCE was detected in only one soil-gas sample at the method detection limit $\left(10 \mu \mathrm{g} / \mathrm{m}^{3}\right)$, suggesting that a source of 1,1-DCE is not located on the site. The soil-gas survey indicated the presence of only very low levels of other VOCs, which also suggests that a source of other VOCs in this area is not likely. The hydraulic connectivity test indicated a connection between the contaminant-bearing zones in the area north and the former Chevron gas station area. Furthermore, the highest concentrations of 1,1-DCE were located north of the area and no evidence of a source of 1,1-DCE existed on the site. The source of 1,1-DCE was probably associated with the northern property. The groundwater samples collected in February 2006 indicated that only one of the four monitoring wells sampled in this area had concentrations of 1,1-DCE above the cleanup goals and standards. Because of the low concentrations, 2,412 gallons of $\mathrm{NaMnO}_{4}$ were injected in four monitoring wells. The concentrations of $\mathrm{NaMnO}_{4}$ ranged from 3 percent to 10 percent.

\subsubsection{Post-remediation risk assessment and regulatory approval}

Of the VOC concentrations detected in groundwater, only TCE required additional evaluation for health risks. Other VOCs did not suggest the potential for significant threats to human health. TCE was detected in groundwater in the former Unit 22 area and in soil-gas at the former Chevron gas station area. A post-remediation risk assessment was performed because the low TCE concentrations in groundwater could theoretically pose a risk to human health (via the vapour intrusion pathway) in residences and commercial structures 
above TCE-impacted groundwater. Based on conservative assumptions and a residential exposure scenario, there was a calculated potential risk above CDPHE's level for risk management decisions (1 in 1,000,000); however, the theoretical risk was less than the CDPHE action level (1 in 10,000 cancer risk) and no greater than the risks associated with exposure to typical indoor air levels of TCE in the Denver area. Concentrations of all other VOCs at the project parcel did not represent potentially significant threats to human health. As an added measure for protecting human health of future occupants (after redevelopment), a passive vapour intrusion barrier (e.g., radon mitigation system) was recommended as an engineering control for development at grade residential use.

Based on completion of the remediation according to the approved cleanup plan, the CDPHE stated that no further action was required to assure that the property was protective of existing and proposed uses and did not pose an unacceptable risk to human health or the environment.

\section{Redevelopment}

Following remediation and determination of no further action by CDPHE, the owner sold the project parcel in 2007 to a commercial developer. The new owner has constructed a mixed residential and retail complex consisting of apartments and retail space. The complex is currently occupied and includes a swimming pool, spa, fitness center, outdoor fireplace court, parking structures and cyber cafe.

\section{Conclusions}

Approaches to redevelopment of contaminated properties vary depending upon many factors, including the type/extent of contamination, human health risk, regulatory agencies, costs, the resources/desires of the owners/developers, and the value and demand for the property. Overall, the remediation and development of project parcel at the former rubber manufacturing site demonstrated the importance of integrating many of these factors including:

- A rapid and flexible voluntary cleanup regulatory program

- Rapid and effective cleanup technologies

- A transit-oriented development approach resulting in high demand for the property.

\section{References}

[1] Olsen, R.L., Woods, A.B. \& Edgar, M.H., Remediation and Development of a Former Military Manufacturing and Test Site in Florida USA, Third International Conference on Prevention, Assessment, Rehabilitation and Development of Brownfield Sites, WIT Transactions on Ecology and the Environment, Vol. 94, WIT Press, Southampton and Boston, pp 121-130, 2006. 
[2] Olsen, R.L. \& Burgess, M.A., Case Histories and Comparison of Two "Brownfields" Sites in Kansas and Indiana USA, Second International Conference on Brownfield Sites: Assessment, Rehabilitation and Development, WIT Press, Southampton and Boston, pp 191-200, 2004.

[3] Whitman, I.L., Brownfield Redevelopment by the Private Sector: Market Driven Decision-making, Third International Conference on Prevention, Assessment, Rehabilitation and Development of Brownfield Sites, WIT Transactions on Ecology and the Environment, Vol. 94, WIT Press, Southampton and Boston, pp 21-27, 2006.

[4] Hugueland, R.P., LaVelle, J.M. \& Olsen, R.L., Remediation and Development of a Former Landfill and Rail Yard in Virginia USA, Fourth International Conference on Prevention, Assessment, Rehabilitation and Development of Brownfield Sites, WIT Transactions on Ecology and the Environment, Vol. 107, WIT Press, Southampton and Boston, pp 79-92, 2008. 